\title{
Biological methods used to assess surface water quality
}

\author{
Natalia Szczerbińska, Małgorzata Gałczyńska
}

Received - 22 May 2015/Accepted - 24 November 2015. Published online: 31 December 2015; @Inland Fisheries Institute in Olsztyn, Poland Citation: Szczerbińska N., Gałczyńska M. 2015 - Biological methods used to assess surface water quality - Arch. Pol. Fish. 24: 185-196.

\begin{abstract}
In accordance with the guidelines of the Water Framework Directive 2000/60 (WFD), both ecological and chemical statuses determine the assessment of surface waters. The profile of ecological status is based on the analysis of various biological components, and physicochemical and hydromorphological indicators complement this assessment. The aim of this article is to present the biological methods used in the assessment of water status with a special focus on bioassay, as well as to provide a review of methods of monitoring water status. Biological test methods include both biomonitoring and bioanalytics. Water biomonitoring is used to assess and forecast the status of water. These studies aim to collect data on water pollution and forecast its impact. Biomonitoring uses organisms which are characterized by particular vulnerability to contaminants. Bioindicator organisms are algae, fungi, bacteria, larval invertebrates, cyanobacteria, macroinvertebrates, and fish. Bioanalytics is based on the receptors of contaminants that can be biologically active substances. In bioanalytics, biosensors such as viruses, bacteria, antibodies, enzymes, and biotests are used to assess degrees of pollution.
\end{abstract}

Keywords: bioanalytics, bioindication, biomonitoring, biotest

\section{Introduction}

Apart from chemical methods, biological methods are being used increasingly often for assessing surface water quality. Thanks to the possibility of omitting the initial stage of sample preparation, analyses conducted using such methods are often less expensive and less time-consuming. Biological test methods include both biomonitoring and bioanalytics. Biomonitoring aims to assess the state of the natural environment and levels of pollution. This method uses plants and animals that serve as bioindicators. Bioanalytics is based on using receptors of pollution with biologically active substances. Biosensors such as viruses, bacteria, enzymes, and antibodies or bioassays can be used to assess levels of environmental pollution (Nałęcz-Jawecki 2003, Traczewska 2011). The aim of this article is to present the biological methods used in the assessment of water status with a special focus on bioassay, as well as to review methods for monitoring water status.

\section{Biomonitoring}

Biomonitoring is one of the three elements of environmental monitoring. The International Organization for Standardization (ISO) defines water monitoring as a planned process of sampling, measuring, and analysing different water features, and they are often designed to test compliance with

\footnotetext{
N. Szczerbińska [ $\left.\Xi^{\circ}\right]$, M. Gałczyńska

Department of General and Ecological Chemistry

West Pomeranian University of Technology, Szczecin, Poland

ul. Słowackiego 17, 71-434 Szczecin

e-mail: Natalia.Szczerbinska@zut.edu.pl
} 
respective standards. Biomonitoring is divided into passive and active. Passive biomonitoring is the use of organisms, organism associations, and parts of organisms which are a natural component of the ecosystem and appear there spontaneously. Active biomonitoring includes all methods which insert organisms under controlled conditions into the site to be monitored.

Biological monitoring relies on two types of organisms: so-called biological indicators characterized by a determined tolerance level to environmental factors, and monitoring organisms capable of accumulating chemical elements or compounds. The selection of the group of organisms used depends on the type of observation (Traczewska 2011).

Methods adopted for assessing surface water quality based on biological indicators have been undergoing development for many years and are still being improved upon; they can be divided into two groups: the saprobic system - planktonic organisms and periphyton (Europe) and the system based on macroinvertebrates (USA). Fish and aquatic plants can also be used as indicator organisms.

\section{Indices based on selected species or groups of organisms}

The saprobic system developed by Kolwitz and Marsson (1909) is the oldest biological method used to assess the quality of surface waters. The relationships between the amount of oxygen dissolved in water and $\mathrm{CO}_{2}$, and the level of organic pollution of water as well as species diversity and abundance of organisms are of crucial importance to this method (Bonada et al. 2006). Originally, the method included categorizing water into three classes: polysaprobic water (high levels of pollution), mesosaprobic water (average levels of contamination), and oligosaprobic water (no pollution). The system was developed further and the number of indicator species was expanded and water classes were supplemented with six additional classes. Nine classes of water quality were designated based on the saprobic index: ksenosaprobic water, oligosaprobic water, $\beta$-mesosaprobic water, $\alpha$-mesosaprobic water, polysaprobic water, isosaprobic water, metasaprobic water, hypersaprobic water, and ultrasaprobic water. Over the years, the system has been modified many times and various versions of the system have been developed (Klimaszyk and Trawiński 2007). Nowadays, in many countries this system has been replaced by biotic indices, point-based systems, and observations of changes in population in individual ecological groups.

The biotic system combines the diversity of defined systematic groups into one index or point scoring. When calculating the biotic index, the abundance of organisms in a sample is not taken into consideration, whereas in the scoring system the parameter is included in the calculation. The general biotic index is used in the assessment of water quality and relies on the analysis of benthic fauna and thanks to the analysis of small vertebrates it allows assessing pollution introduced to flowing waters (Lavado et al. 2006). A profile of selected biotic systems is presented in Table 1 (Woodiwiss 1964, Chandler 1970, Armitage et al. 1983, Cota et al. 2003, Scardi et al. 2006, Klimaszyk and Trawiński 2007, Traczewska 2011, Królak et al. 2011).

The BMWP Score has been modified for use in many countries, e.g., in Poland, this system is called the BMWP-PL. It is a combination of the biodiversity index and the Polish biotic index. In this method, taxa present in a given area of a river are identified and assigned a specific number of points. Then the index values are calculated. Margalef's equation is used to calculate the biodiversity index (Hering el al. 2006, Klimaszyk and Trawiński 2007, Królak et al. 2011).

Another index developed to facilitate observations of changes in water quality is the Index of Biotic Integrity (IBI) which is based on the use of fish. The quality of the aquatic environment of a given group of fish was assessed in comparison to undisturbed environments corresponding to the environment under analysis. This index takes into account the composition of species, diversity, trophic relationships, size, and condition of fish. Water is classified according to 


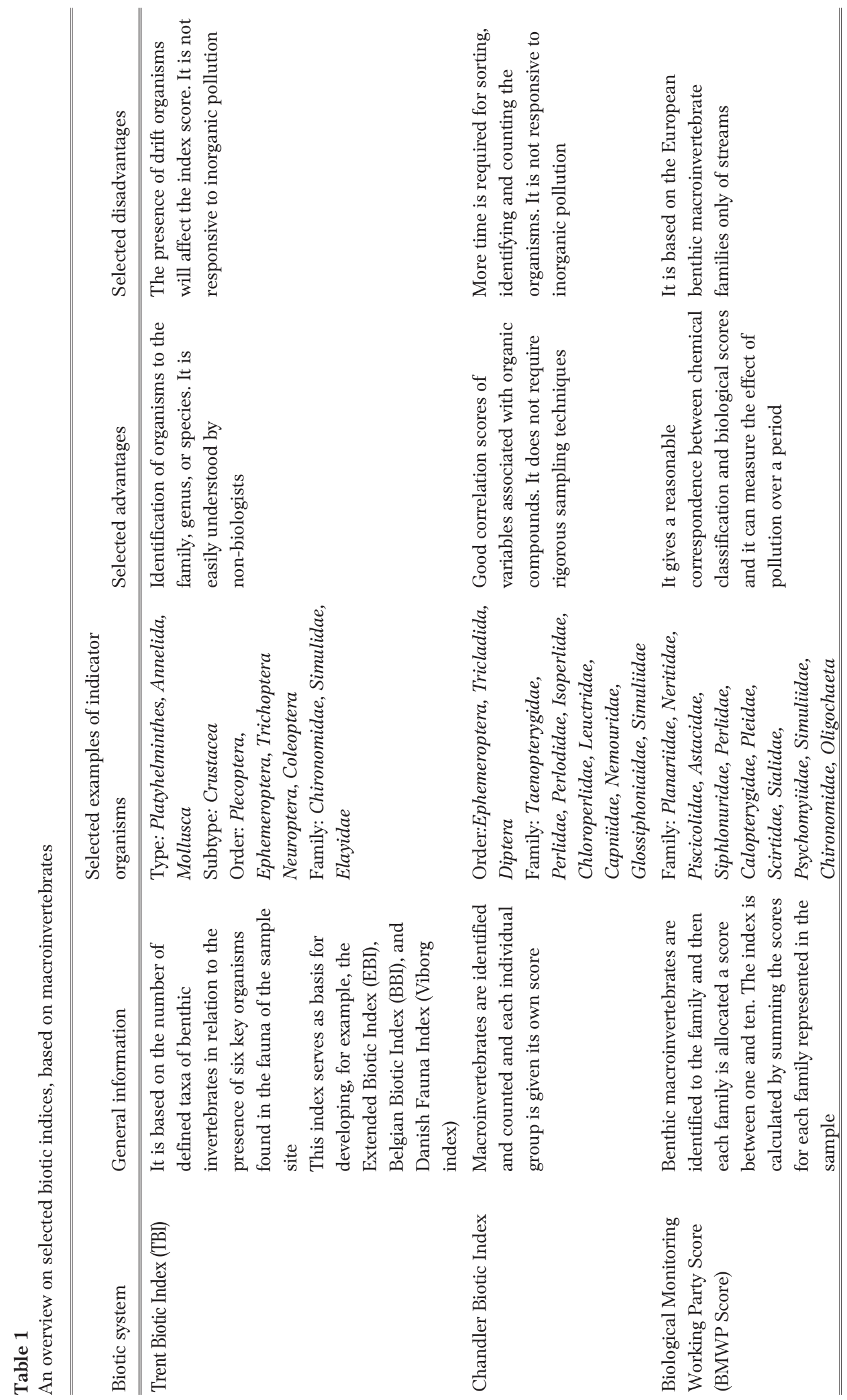


three classes (Klimaszyk and Trawiński 2007). Bioindicators most sensitive to water pollution are brown trout Salmo trutta L., roach, Rutilus rutilus (L.), and pikeperch Sander lucioperca (L.). Slightly less sensitive species used as bioindicators are carp, Cyprinus carpio L., bream, Abramis brama (L.), and perch, Perca fluviatilis L. Fish can serve as indicators of accumulation or sensitivity. The European Fish Index (EFI) was developed based on the IBI in 2004. Because of its limitations (oversimplified database), it was further developed into the new European Fish Index (EFI+) based on a database compiled from more than 14,000 stations located in 2,700 rivers in 15 European countries (EFI+ Manual 2009, Adamczyk et al. 2013).

Many aquatic species show specific bioaccumulative abilities. These include:

- C. carpio: heavy metals, polycyclic aromatic hydrocarbons (PAHs), pesticides, polychlorinated biphenyls (PCB), dioxins (Oikari 2006, Klobučar et al. 2010);

- S. trutta: non-steroidal anti-inflammatory drugs, PAHs, pesticides, PCB, dioxins (Scardi et al. 2006, Fent 2008);

- Dreissena sp. and Mutiluss sp.: cadmium, PCB (Traczewska 2011);

- Myriophyllum propinquum A. Cunn.: arsenic (Robinson et al. 2006);

- Centella asiatica L.: copper (Mokhtar et al. 2011);

- Eichhornia crassipes (Mart.) Solms: zinc and chromium (Zayed and Terr 2003, Aisien et al. 2010);

- Lemna minor L.: lead (Prasad et al. 2001);

- Pitia stratiotes L.: chrome (Odjegba and Fasidi 2004);

- Salvinia minima Baker: cadmium (Olguín et al. 2002).

\section{Community structure indices}

The description of a population's response to environmental disturbance is based on diversity coefficients. Three structural population parameters are used in calculations: its size, abundance, and uniformity. Three equations are also used for to assess diversity: Shannon-Wiener, Simpson, and Margalef. The coefficients of diversity are independent of the size of the sample as they are quantitative and dimensionless. The disadvantage lies in the fact that the values change depending on the equation used and in that tolerance, sensitivity, and methodology of identification of the organisms are not taken into consideration. In order to facilitate the assessment of biocenosis, this method was modified by the introduction of the Sequential Comparative Index (SCI). This system includes the random selection of organisms from the analysed sample and is used to determine the number of series on the grounds of morphological similarity of the organisms. SCI is the quotient of the number of series divided by the number of selected organisms. The values of the index range from 0.1 to 1.0 and the higher the values, the greater the diversity (Traczewska 2011).

\section{Macrophytes as indicators of trophic status}

In European Union countries, the Water Framework Directive (WFD) is the key document that sets forth the rules for the conservation of inland surface, transitional, coastal, and underground waters. The requirements in the document must be met by individual types of waters. Waters of moderate quality are characterized by moderate disturbances in the values of biological elements, whereas waters of poor or bad ecological quality have values below moderate levels (Hutorowicz and Napiórkowska-Krzebietke 2014). In the WFD, macrophytes are recognized as important for determining the ecological status of water bodies (EC 2000). Species indicator values can vary significantly depending on river or lake type and are therefore unsuitable for detecting differences in ecological tolerances of species across Europe. Many macrophyte methods are used to assess the trophic states of water bodies in Europe: the Macrophyte Index (MI, lake) and the Trophic Index of Macrophytes (TIM, river) in Germany, the Mean Trophic Rank 
(MTR, river) in the UK, Indice biologique macrophytique en riviére (IBMR, river) in France, the Ecological State Macrophyte Index (ESMI, lake) and Macrophyte River Index (MRI, river) in Poland (Szoszkiewicz et al. 2009).

The MI (Melzer 1999) is applicable in calcareous lakes in the Alps and the pre-alpine region. A total of 45 species of submerged macrophytes is included in a catalog of nine indicator groups. The mean MI of a lake correlates with its total phosphorus concentration during circulation time. The ESMI was developed in 2006 for two types of lakes (charophyte-colonized stratified and non-stratified lakes). The ESMI evaluates two aspects of the macrophyte community, namely taxonomic composition and abundance, which are combined into one multimetric index. ESMI is calculated by examining plants along designated lake transects $20-30 \mathrm{~m}$ in width. The number of transects depends on the shoreline and the area of the lake. The ESMI values range from 0 to 1 , where 1 denotes pristine conditions and 0 highly degraded habitats (Ciecierska and Kolada 2014).

The MTR is a method focused on the impacts caused by phosphate enrichment (Dawson et al. 1999, Holmes et al. 1999). Each of 129 aquatic plant species is allocated a Species Trophic Rank (STR) score according to its response to eutrophication. A low STR indicates that the plant is either tolerant of eutrophication or alternatively has no preference and is termed "cosmopolitan". The MTR of a sampling site is expressed by integrating the STRs of the species present at a site as a mean value, weighted according to the relative percentage cover of the individual species. In TIM (Schneider and Melzer 2003) macrophyte indicator values are given for a total of 49 species of submerged macrophytes on a scale from 1 to 4 (1 indicating oligotrophic and 4 polytrophic conditions). The IBMR is applicable to natural and artificial running waters. Each of 207 taxa is allocated a cote spécifique according to its response to eutrophication. IBMR species values range from 0 to 20 with 0 indicating hypertrophic and 20 indicating oligotrophic conditions. The Macrophyte River Assessment Method (MMOR) has been used in Poland since 2007. This method employs the quantitative and qualitative characteristics of macrophytes in the section of river under analysis. This method allows establishing the level of river degradation and determining its trophy using the Macrophyte Index for Rivers (MIR) (Szoszkiewicz et al. 2009).

\section{Biotests}

Biotests are based on using living organisms that react in a specific way to the pollution of water with metal, organic (e.g.: PAHs, PCB, pesticides, pharmaceuticals), and biogenic compounds. The analyses are conducted in laboratories rather than in the field. Different publications adopt various criteria for distinguishing the analyses based on tests, yet the most popular criterion is the type of organism used in the analysis. Biotests use both animal and plant organisms. Detecting viruses and bacteria that pollute water is possible using biotests (Markert et al. 2012, Sadowska 2012). Biotests allow identifying toxic, mutagenic, or carcinogenic substances in an analysed sample of water and facilitate the assessment of the effect these substances have on organisms. For this purpose, the values of indices are calculated based on the dose-response relationship. The indices determining toxicity are Effective Concentration $\left(\mathrm{EC}_{25}, \mathrm{EC}_{50}\right)$ and Effective Dose $\left(\mathrm{ED}_{25}\right.$ $\mathrm{ED}_{50}$ ). The parameters describe the concentration of a given toxic substance in an environment or its dose which produces ( 25 or $50 \%$ ) a given biological effect to a previously specified extent. It is also possible to determine the level of a toxic factor present in the environment which results in weakening or hindering a particular process, which is known as Inhibition Concentration $\left(\mathrm{IC}_{50}\right)$. In the case of acute toxicity, it is the Lethal Dose $\left(\mathrm{LD}_{50}\right)$ and Lethal Concentration $\left(\mathrm{LC}_{50}\right)$ that is the lethal dose and concentration which results in death after a specified time in half of the organisms under study. When determining the dose and exposition time to a given toxic substance, the concentration values or dose limit are established:

- No Observed Effect Level/Concentration (NOEL, NOEC); 
- Lowest Observed Effect Level/Concentration (LOEL, LOEC);

- No Observed Adverse Effect Level (NOAEL);

- Lowest Observed Adverse Effect Level (LOAEL).

These are measured as mg or $\mu \mathrm{g}$ of a given substance per $1 \mathrm{~kg}$ of body mass of an organism in a 24-hour period (Napiórkowski et al. 2008).

\section{Bacterial tests}

The most commonly used bacteria in biological tests are the species Vibrio fischeri and Vibrio harveyi, which are capable of luminescence. They are Gram-negative, curved-rod shaped, facultatively aerobic bacteria with polar flagella. Salt water is their natural habitat (Girotti et al. 2002, Nałęcz-Jawecki 2003, Danyluk et al. 2007, Traczewska 2011). Bacteria of this species can emit green-blue light (wavelength $490 \mathrm{~nm}$ ) thanks to a specific set of genes the so-called lux operon. In bacteria characterized by luminescence, luciferin is oxidized by the enzyme luciferase. Luciferase is bound through oxygen with a reduced flavin mononucleotide which acts as a cofactor. As a result, luciferase transforms aldehyde into fatty acid and attains higher energy levels. The result of this is oxyluciferin. The particles of oxyluciferin move from an excited state to a ground state and cause luminescence, and the cofactor is oxidized to flavin mononucleotide. This process can be represented with the following equation (Pogorzelec and Piekarska 2013):

$$
\begin{aligned}
\mathrm{FMNH}_{2} & +\mathrm{RCHO}+\mathrm{O}_{2} \rightarrow \mathrm{FMN}+\mathrm{RCOOH} \\
& +\mathrm{H}_{2} \mathrm{O}+\mathrm{hv}(490 \mathrm{~nm})
\end{aligned}
$$

Many factors affect bacterial luminescence. Bacteria emit light under optimal conditions using 10\% of the energy coming from metabolism. When harmful compounds affect bacteria their metabolism is disturbed, thus their ability to luminescence is inhibited. The loss of luminescent abilities is proportional to the amount of harmful compounds affecting the bacteria (Steliga et al. 2009, Pasternak et al. 2010). Microorganisms are used in the screening tests such as Microtox, LUMIStox, ToxAlert 10, and ToxAlert 100. They are characterized by good sensitivity and reproducibility, and relatively quick result times (Dewhurst et al. 2002, Danyluk et al. 2007, Traczewska 2011).

Microtox systems are based on the decreasing bacterial luminescence of $V$. fischeri in the presence of a given substance over a specified period of time (5 or $15 \mathrm{~min}$ ) depending on the test selected. The test is conducted according to the procedures specified by the manufacturer, and the change in luminescence is measured with a photometer (Guzzella 1998, Pasternak et al. 2010, Arendarczyk et al. 2011). Lyophilized bacteria, which can be stored for one year at a temperature of $-20^{\circ} \mathrm{C}$, are used for the test (Steliga et al. 2009). Prior to the test, the bacteria are suspended in deionized water. Having read the results, the calculations should be carried out using software recommended by the manufacturer (Pasternak et al. 2010). Another species used in biotests is Salmonella typhimurium, which a Gramm-negative, facultatively anaerobic bacteria. The bacteria are used in the Ames test to detect, among other things, mutagenic substances (DeLuca et al. 1983). This procedure permits determining primary mutations in many Salmonella typhimurium LT2 strains (Kołwzan 2009). The strains used in the test are incapable of histidine synthesis, yet when affected by mutagenic substances the mutations are reversed and the strains are capable of histidine synthesis (Kołwzan and Traczewska 1994). This test can be conducted with classical methods (plate counting method) or biosensors. The sensor, which is placed in a culture devoid of histidine, reacts with the decrease in current intensity when in the presence of a mutagen. During Mutatests and Vitotoxs, additional genes responsible for luminescence are introduced to the strains. As a result of the action of a substance damaging DNA, luciferin synthesis is restored and light is emitted (Sun and Stahr 1993, Verschaeve et al. 1999, Węgrzyn and Czyż 2003, Kołwzan 2009, Steliga et al. 2009). Bacillus subtilis, a common Gram-positive bacteria, have the ability to decompose organic substances of plant origin. $\mathrm{Mu}$ tant B. subtilis are used in repair tests aimed at 
analysing the effect of mutagenic compounds on the increased mortality of the analysed cells. The mutant bacteria are incapable of recombinant repair rec-assay, i.e. they do not utilize one of the DNA repair pathways of a cell. Damage to this pathway affects other pathways as well. The cells become more susceptible to DNA damage and even with the slightest damage cell growth can be inhibited. In this test mutagenic compounds result in DNA degradation and cell growth inhibition, yet they do not cause mutation (Karube and Tamiya 1987, Kołwzan 2009).

Escherichia coli are facultatively anaerobic, Gram-negative bacteria naturally present in the large intestines of humans and warm-blooded animals. The strains of the bacteria are used in SOS-Chromotest to detect compounds which may affect DNA leading to its destruction. The test is based on the induction of a sfiA gene function as a result of the action of chemical compounds. The level of expression of induced genes is measured with a colorimeter as $ß$-alactosidase activity. The process occurs through the fusion of gene operons: sfiA (part of the SOS repair system) and lacZ (responsible for galacrosidase synthesis) (Quillardet et al. 1982, Mankiewicz et al. 2002, Płaza et al. 2005). SOS is an induction system which activates at the risk of cell death. In a cell with improved DNA it is repressed by a lexA protein. As a result of DNA damage, the level of the $\operatorname{rec} A+$ gene product increases leading to the modification of DNA III polymerase by the protein. The polymerase continually replicates DNA joining random alkali against fragments of damaged DNA. As a result, the number of mutations in a cell increases, yet the cell survives. Additionally, induction leads to increases in the proteolytic activity of the rec $A$ protein, which results in lex $A$ protein degradation and the derepression of the SOS system (Quillardet et al. 1982).

E. coli are used in the Colitag ${ }^{\mathrm{TM}}$ and Colilert tests conducted with the aim of assessing water quality in terms of microbiological pollution. The Colitag ${ }^{\mathrm{TM}}$ test is based on the identification of $\beta$-glucuronidase, an enzyme characteristic of E. coli, and $\beta$-galactosidase, from coliform bacteria. Ortho-nitrophenyl- $\beta$-D-galactopyranoside (ONPG) chromogenic substrate is used to determine the amount of coliform bacteria. The substrate shows a yellow coloration in the presence of the bacteria following hydrolysis by $\beta$-galactosidase in a sample of water. However, in order to detect $E$. coli bacteria in a sample of water, a fluorogenic substrate characteristic of $\beta$-glucocuronidase is used. The side effect of the reaction is fluorescence. The results of the test are obtained in approximately 24 hours (Trepeta and Edberg 1984, Covert et al. 1989, 1992, Edberg et al. 1989, 1990, Bej et al. 1991, Rompré et al. 2002, Kołwzan 2009, Nikaeen et al. 2009). In turn, the Colilert test relies on using O-nitrophenyl- $\beta$-D-glucuronate (characteristic for coliform bacteria) and 4-methylumbelliferyl- $\beta$-D-glucuronide (MUG) (characteristic for E. coli) (Chang et al. 1989, Olson 1991).

Enterolert is used to determine fecal contamination in water. This test is also based on MUG and fluorescence and operates on similar principles as the two tests described above (Abbott et al. 1998, Eckner 1998, Maheux et al. 2009).

In the analysis of a water sample, test packages based on different strains of bacteria are used; for example, the MARA test (Microbial Assay for Risk Assessment) which, apart from bacteria, uses yeast. The indicator employed in this test is the change of color of bacteria strains and yeast because of inhibited metabolism. The characteristic equation of metabolism inhibition allows for the approximate determination of the type of pollution. Bacterial luminescence is recorded using a luminometer, and then it is computer-processed (Gabrielson et al. 2003, Wadhia et al. 2007).

\section{Biological tests using animals}

In biological tests of water quality conducted on animals, the most commonly used species is Daphnia magna, an invertebrate with a well-developed digestive tract and a relatively small size (female approx. 2-6 mm, male approx. 2.2-3.5 mm). Daphnia magna is naturally present both in permanent and seasonal 
water reservoirs. Crustaceans are used, among others, in the IQ-Tox ${ }^{\mathrm{TM}}$ test, which is intended to detect toxic substances present in drinking water. The test consists of observing the feeding of the analysed organisms with galactose-a substrate labelled with a fluorogenic marker. If there are chemical pollutants present in the water, the processes of sugar decomposition and the release of fluorogenic markers are disturbed, thus disturbing the organism's ability to luminesce. It takes 75 minutes to assess water quality with this test (Kühn et al. 1989, Kołwzan 2009). Daphnia magna is also used in a test for acute toxicity (determinations of the share of organisms showing lethal effects) and chronic toxicity (decrease in reproduction) (Nikitin 2014).

Biological tests are also conducted using mussels from the genus Anodonta (length $10 \mathrm{~cm}$ ) which live in stagnant and flowing waters and filter feed on phytoplankton and zooplankton. Water treatment plants use short-term mussel farming. Mussels close their shells when the level of pollution is water is high. Therefore, observations of mussels permits assessing changes in water quality as the mussels are sensitive to pollution and live in very pure waters (Markert et al. 2012). Mussels of the genus Anodonta are particularly sensitive to increased levels of Fe, $\mathrm{N}-\mathrm{NH}_{4}$, or $\mathrm{Cl}$ in water. They also react if the water is polluted with $\mathrm{Cd}, \mathrm{Cu}, \mathrm{Hg}$, plant protection products, or formaldehyde (Couillard et al. 1993).

Artemia salina is a stenothermal crustacean present only in salt water. The length of an adult form can reach $15 \mathrm{~mm}$. This crustacean is resistant to high concentrations of chlorides in water. Artemia larvae are used in a test which consists of determining the number of organisms in lethal stage in a given water sample. The test is carried out in salt water for 24 hours. Dead organisms are counted using a magnifier (Napiórkowski et al. 2008).

Hydra attenuata is a species of Hydra measuring from 5 to $22 \mathrm{~mm}$ in length. This hydra is found in stagnant or slow-moving fresh waters. Its cylindrical body is white-pink in color and has a radial symmetry. It is highly sensitive to water pollution, and it is used for testing. The adult, non-budding forms of normal morphology are placed in water for 96 hours and observed using a magnifier. In case of water pollution, morphological changes will be observed in the organisms. Five stages of such changes have been identified: organisms without any morphological changes; organisms with thickened tentacle ends; organisms with shortened tentacles; organisms in lethal stage caused by the so-called tulip stage; disintegration of the organism (Trottier et al. 1997, Napiórkowski et al. 2008).

The water quality test packages available on the market use a number of indicator organisms. Toxkit is an example of a test which includes exposure of organisms to water samples for a period of 24 to 74 hours. The number and length of live organisms is determined in each plate well, thus the survival and growth rates are identified (Dewhurst et al. 2002, Wolska et al. 2008, Steliga et al. 2009, Arendarczyk et al. 2011). Tests such as Toxkit are user-friendly and provide good sensitivity, repeatability, and relatively short time of analysis. These tests are in line with guidelines set forth by the OECD, the ISO, and the USEPA (Nałęcz-Jawecki 2003) (Table 2).

\section{Biological tests using plants}

Tests with plant organisms can be used to assess the condition of surface waters. For example, the freshwater algae growth inhibition test uses chlorophyta: Pseudokirchneriella subcapitata - microalgae with a sickle-shaped body 8-14 $\mu \mathrm{m}$ in size, and Desmodesmus subspicatus - oval-shaped algae 7-15 $\mu \mathrm{m}$ in size. The algae are sensitive to harmful substances in water, including trace metals. The organisms are incubated with harmful substances in a static culture at a temperature of $21-24^{\circ} \mathrm{C}$ for 72 hours, then the increase in biomass or the inhibition of biomass increase is measured (OECD 2011).

Lemna minor, a freshwater plant, is one of the world's smallest vascular plants (2-7 $\mathrm{mm}$ wide). Thanks to high adaptability, it has a cosmopolitan distribution, yet it is also sensitive to pollution. As a floating plant, Lemna minor is at risk from the toxic action of surfactants or hydrophobic substances 
Table 2

Comparison of toxkit package test

\begin{tabular}{|c|c|c|c|c|}
\hline Indicator organism & Test & Realization time & Result & Norm \\
\hline Brachionus calyciflorus & Acute rotoxkit F & 24 hours & Death rate percent & ASTM E1440-91 \\
\hline Brachionus calyciflorus & $\begin{array}{l}\text { Short-chronic } \\
\text { Rotoxkit F }\end{array}$ & 48 hours & Inhibition of growth & $\begin{array}{l}\text { AFNOR T90-377, ISO } \\
20666\end{array}$ \\
\hline Brachionus plicatilis & Rotoxkit M & 24-48 hours & Death rate & ASTM E1440-91 \\
\hline Larvae of the saltwater genus & Artoxkit M & 24-48 hours & Death rate & \\
\hline Artemia & & & & ASTM E1440-91 \\
\hline Daphnia magna, Daphnia pulex & Daphtoxkit F & 48 hours & $\begin{array}{l}\text { Immobilization, death } \\
\text { rate percent }\end{array}$ & $\begin{array}{l}\text { OECD Guideline 202, } \\
\text { ISO } 6341\end{array}$ \\
\hline Ceriodaphnia dubia & Ceriodaphtoxkit F & 24 hours & Death rate percent & $\begin{array}{l}\text { OECD Guideline 202, } \\
\text { ISO } 6341\end{array}$ \\
\hline Thamnocephalus platuyurus & Thamnotoxkit F & 24-48 hours & Death rate percent & ISO 14380 \\
\hline Thamnocephalus platuyurus & Rapidtoxkit F & 30-60 minutes & Reduction or no food & ISO 14380 \\
\hline Tetrahymena thermophila & Protoxkit F & 24 hours & Inhibition of growth & OECD Guideline 202 \\
\hline Selenastrum capricornutum & Algaltoxkit F & 72 hours & Inhibition of growth & $\begin{array}{l}\text { ISO 8692, OECD } \\
\text { Guideline } 201\end{array}$ \\
\hline
\end{tabular}

present on the surfaces of water as well as pollution with trace metals. The test that uses this plant is conducted according to standard ISO or OECD procedures. After 7 days, the influence of the analysed compounds on plant growth is determined. Toxic compounds can induce changes in the number and morphology of roots, the number and surface of fronds, and the number of plants in dry and fresh biomass (Orzechowski 2005, Bielińska and Nałęcz-Jawecki 2009).

Bioanalysis can also be based on using biosensors, which are a combination of classical analysis and modern technology. Biosensors are small in size, highly sensitive, selective, and not susceptible to interference (Filipiak et al. 1996, Matejczyk and Suchowierska 2011). They can be used for a long period of time and therefore are applied in many analytic and diagnostic techniques. The sensor comprises a biologically active material and a transducing element that detects the activity and concentration of a given chemical substance in the sample (Pogorzelec and Piekarska 2013). The biosensor uses a biological detection system (e.g. microorganism, an antibody, an enzyme, or DNA) and a transducer (detector), which converts biological processes into an electrical signal. They can be categorized as catalyst-based and receptor-based biosensors depending on the biological material used for detection. The detectors can also be classified according to the type of phenomenon used in the detection process: electrochemical, potentiometric, conductometric, amperometric, piezoelectric, optical, or thermal. The application of biosensors based on a combination of biological and electronic components is a quick, precise, sensitive method of detecting even the smallest amounts of chemical compounds, toxins, or microorganisms (Kołwzan 2009).

\section{Conclusions}

Increasingly more chemical and biological substances that have either direct or indirect effects on aquatic ecosystems and human health are introduced to surface waters. Therefore, monitoring water quality is crucial. The aim of water quality analysis is to monitor concentrations of substances introduced to waters by anthropogenic pollution. Over the years, biological methods of water quality assessment have been 
developed substantially. Such methods are increasingly incorporated into technological solutions, i.e., the use of biosensors or biologically active deposits in water purification. The advantage of biological methods is that water quality assessment is conducted in the same way as a living organism would react to pollution. The reactions of living organisms to pollution are manifested in physiological, morphological, and behavioral changes. Moreover, it is possible to forecast changes occurring in aquatic environments. Research based on the use of biological methods is often less expensive and time-consuming since some stages of sample preparation can be omitted. The advantage of such methods is that the analysis can be conducted in a laboratory as well as in the natural habitat of the organisms used for testing (Nałęcz-Jawecki 2003, Traczewska 2011). Biotests can also be used to supplement standard analyses since different methods can be applied to conduct environmental tests. Particular tests are characterized by different sensitivity to various compounds; therefore, the use of multiple testing methods is recommended in order to obtain more reliable results (Codina et al. 1994).

Author contribution. N.S. and M.G. conceived of and designed the study, conducted literature review and wrote the paper.

\section{References}

Abbott S., Caughley B., Scott G. 1998 - Evaluation of Enterolert ${ }^{\circledR}$ for the enumeration of enterococci in the marine environment - New Zeal. J. Mar. Fresh. Res. 32: 505-513.

Adamczyk M., Prus P., Wiśniewolski W. 2013 - Possibilities of applying the European Fish Index (EFI+) to assess the ecological status of rivers in Poland - Rocz. Nauk. PZW. 26: 21-51 (in Polish).

Aisien F.A., Faleye O., Aisien E.T. 2010 - Phytoremediation of heavy metals in aqueous solutions - Leonardo J. Sci. 17: 37-46.

Arendarczyk A., Zgórska A., Grabińska-Sota E. 2011 - Toxicity of 1-heksyl-3-methylimidazolium chloride according to selected marine and freshwater organisms - Inż. Ochr. Środow. 14: 137-143 (in Polish).

Armitage P.D., Moss D., Wright J.T., Furse M.T. 1983 - The performance of a new biological water quality score system based on macroinvertebrates over a wide range of unpolluted running-water sites - Water Res. 17: 333-347.

Bej A.K., DiCesare J.L., Haff L., Atlas R.M. 1991 - Detection of Escherichia coli and Shigella spp. in water by using the polymerase chain reaction and gene probes for uid Appl. Environ. Microbiol. 57: 1013-1017.

Bielińska M., Nałęcz-Jawecki G. 2009 - Pharmaceuticals in the environment: I: Evaluation of toxicity of three fluoroquinolones to duckweed Lemna minor - Biul. Wydz. Farm WUM. 4: 24-30 (in Polish).

Bonada N., Prat N., Resh V.H., Statzner B. 2006 - Developments in aquatic insect biomonitoring: a comparative analysis of recent approaches - Annu. Rev. Entomol. 51: 495-523.

Chandler J.R. 1970 - A biological approach to water quality management - Water Polut. Control 69: 415-422.

Chang G.W., Brill J., Lum R. 1989 - Proportion of $\beta$-D-glucoronidase-negative Escherichia coli in human fecal samples - Appl. Environ Microbiol. 55: 335-339.

Ciecierska H., Kolada A. 2014 - ESMI: a macrophyte index for assessing the ecological status of lakes - Environ. Monit Assess. 186: 5501-5517.

Codina J.C., Perez-Garcia A., De Vicente A. 1994 - Detection of heavy metal toxicity and genotoxicity in wastewaters by microbial assay - Wat. Sci. Tech. 30: 145-151.

Cota L., Goulart M., Moreno P., Callisto M. 2003 - Rapid assessment of river water quality using an adapted BMWP index: a practical tool to evaluate ecosystem health - Verh. Internat. Verein. Limnol. 28: 1713-1716.

Couillard Y., Campbell P.G., Tessier A. 1993 - Response of metallothionein concentrations in a freshwater bivalve (Anodonta grandis) along an environmental cadmium gradient - Limnol. Oceanogr. 38: 299-313.

Covert T.C., Shadix L.C., Rice E.W., Haines J.R., Freyberg R.W. 1989 - Evaluation of the Autoanalysis Colilert test for detection and enumeration of total coliforms - Appl. Environ. Microbiol. 55: 2443-2447.

Covert T.C., Rice E.W., Johnsons S.A., Berman D., Johnson C.H., Mason P.J. 1992 - Comparing defined-substrate tests for the detection of Escherichia coli in water - J. Am. Water Works Assoc. 84: 98-105.

Danyluk B., Uchman W., Konieczny P., Bilska A. 2007 - An objective method to assess bioluminescent properties of selected bacterial strains - Acta Sci. Pol., Technol. Aliment. 6: 5-16.

Dawson F.H., Newman J.R., Gravelle M.J., Rouen K.J., Henville P. 1999 - Assessment of the trophic status of rivers using macrophytes. Evaluation of the mean trophic rank. - R\&D Technical Report E39, Environment Agency of England \& Wales, Bristol, UK.

DeLuca S.J., Chao A.C., Smallwood Jr. C. 1983 - Ames test of ferrate treated water - J. Environ. Eng. 109: 1159-1167.

Dewhurst R.E., Wheeler J.R., Chummun K.S., Mather J.D., Callaghan A., Crane M. 2002 - The comparison of rapid bioassays for the assessment of urban groundwater quality - Chemosphere 47: 547-554. 
EC - European Communities 2000 - Directive 2000/60/EC of the European Parliament and of the Council of 23 October 2000 establishing a framework for Community action in the field of water policy - OJ L. 22.12.2000: 327.

Eckner K.F. 1998 - Comparison of membrane filtration and multiple-tube fermentation by the Colilert and Enterolert methods for the detection of waterborne coliform bacteria, Escherichia coli, and enterococci used in drinking and bathing water quality monitoring in southern Sweden - Appl. Environ. Microbiol. 64: 3079-3083.

Edberg S.C., Allen M.J., Smith D.B., Kriz N.J. 1990 - Enumeration of total coliforms and Escherichia coli from source water by the defined substrate technology - Appl. Environ. Microbiol. 56: 366-369.

Edberg S.C., Allen M.J., Smith D.B. 1989 - Rapid specific autoanalytical method for the simultaneous detection of total coliforms and E. coli from drinking water - Water Sci. Technol. 21: 173-177.

EFI+ Manual. 2009 - Manual for the application of the New European Fish Index - http://efi-plus.boku.ac.at/software/doc/EFI+Manual.pdf. Date of reading 27.10.2015.

Fent K. 2008 - Effects of pharmaceuticals on aquatic organisms - Pharmaceuticals in Environment: 175-203.

Filipiak M., Fludra K., Gościmińska E. 1996 - Enzymatic membranes for determination of some disaccharides by means of an oxygen electrode - Biosens. Bioelectron. 11: 355-364.

Gabrielson J., Kühn I., Colque-Navarro P., Hart M., Iversen A., McKenzie D., Möllby R. 2003 - Microplate-based microbial assay for risk assessment and (eco)toxic fingerprinting of chemicals - Anal. Chim. Acta 485: 121-130.

Girotti S., Bolelli L., Roda A., Gentilomi G., Musiani M. 2002 Improved detection of toxic chemicals using bioluminescent bacteria - Anal. Chim. Acta 471: 113-120.

Guzzella L. 1998 - Comparison of test procedures for sediment toxicity evaluation with Vibrio fischeri bacteria Chemosphere 37: 2895-2909.

Hering D., Johnson R.K., Kramm S., Schmutz S., Szoszkiewicz K., Verdonschot P.F. 2006 - Assessment of European streams with diatoms, macrophytes, macroinvertebrates and fish: a comparative metric-based analysis of organism response to stress - Freshw. Biol. 51: 1757-1785.

Holmes N.T.H., Newman J.R., Chadd S., Rouen K.J., Saint L., Dawson F.H. 1999 - Mean trophic rank: A user's manual R\&D Technical Report E38 - Environment Agency of England\&Wales, Bristol, UK, 156 p.

Hutorowicz A., Napiórkowska-Krzebietke A. 2014 - The European Union Water Framework Directive and the ecological status assessment of inland waters - Arch. Pol. Fish. 22: 3-5.

Karube I., Tamiya E. 1987 - Biosensors for environmental control - Pure. Appl. Chem. 59: 545-554.

Klimaszyk P., Trawiński A. 2007 - Assessment of rivers based on benthic macroinvertebrates - Indeks BMWP-PL Poznań, 2-6 (in Polish):
Klobučar G.I., Štambuk A., Pavlica M., Perić M.S., Hackenberger B.K., Hylland K. 2010 - Genotoxicity monitoring of freshwater environments using caged carp (Cyprinus carpio) - Ecotoxicology 19: 77-84.

Kolwitz R., Marsson M. 1909 - Ecology of animal saprobia In: Biology of water pollution (Eds) L.E. Keup, W.M. Ingram, K.M. Mackenthun, U.S.D.I., Fed. Water Pollut. Control. Admin. Cincinnati, 47-52 pp.

Kołwzan B. 2009 - Use of biosensors for the assessment of water quality - Ochr. Śr. 31:3-14 (in Polish).

Kołwzan B., Traczewska T.M. 1994 - The presence of contaminants with mutagenic and carcinogenic in water Oława River - Ochr. Śr. 3-4: 25-28 (in Polish).

Królak E., Korycińska M., Mazurek I., Szynkarczyk O. 2011 Using of a simple bioindication method in the assessment of rivers water quality in school conditions - Chemia Dydaktyka Ekologia Metrologia. 16: 93-96 (in Polish).

Kühn R., Pattard M., Pernak K-D., Winter A. 1989 - Results of the harmful effects of water pollutants to Daphnia magna in the 21 day reproduction test - Water Res. 23: 501-510.

Lavado R., Ureńa R., Martin-Skilton R., Torreblanca A., Del Ramo J., Raldúa D., Porte C. 2006 - The combined use of chemical and biochemical markers to assess water quality along the Ebro River - Environ. Pollut. 139: 330-339.

Maheux A.F., Picard F.J., Boissinot M., Huppe V., Bissonnette L., Bernier J.L.T., Cantin P., Huletsky A., Bergeron M.G. 2009 Analytical limits of three $\beta$-glucosidase-based commercial culture methods used in environmental microbiology, to detect enterococci - Water Sci. Technol. 60: 943-954.

Mankiewicz J., Walter Z., Tarczyńska M., Palyvoda O., Wojtysiak-Staniaszczyk M., Zalewski M. 2002 - Genotoxicity of cyanobacterial extracts containing microcystins from Polish water reservoirs as determined by SOS chromotest and comet assay - Environ. Toxicol. 17: 341-350.

Markert B., Wünschmann S., Diatta J., Chudzińska E. 2012 Innovative observation of the environment bioindicators and biomonitors: definitions, strategies and applications - Ochr. Śr. Zasobów Nat. 53: 115-152.

Matejczyk M., Suchowierska M. 2011 - Characteristics of the phenomenon of quorum sensing and its meaning in terms of the formation and functioning of biofilm in environmental engineering, civil engineering, medicine and households - Budownictwo i Inżynieria Środowiska 2: 71-75 (in Polish).

Melzer A. 1999 - Aquatic macrophytes as tools for lake management - Hydrobiologia 395: 181-190.

Mokhtar H., Morad N., Fizri F.F.A. 2011 - Phytoaccumulation of Copper from aqueous solutions using Eichhornia crassipes and Centella asiatica - IJESD 2: 205-210.

Nałęcz-Jawecki G. 2003 - Aquatic toxicity test method bioindicative - Biul. Farmac. 2: 34-39.

Napiórkowski P., Florkiewicz S., Ślebioda K., Kentzer A. 2008 - Surface water quality ecotoxicological assessment of the Torun area using bioassays with Artemia salina and Hydra attenuate - I: Ekotoksykologia w ochronie 
środowiska (Eds) B. Kołwzan, K. Grabas, Wydawnictwo PZITS: 249-258 (in Polish).

Nikaeen M., Pejhan A., Jalali M. 2009 - Rapid monitoring of indicator coliforms in drinking water by an enzymatic assay - Iran. J. Environ. Health Sci. Eng. 6: 7-10.

Nikitin O. 2014 - Aqueous medium toxicity assessment by Daphnia magna swimming activity change - Adv. Environ. Biol. 8: 74-78.

Odjegba V.J., Fasidi I.O. 2004 - Accumulation of trace elements by Pistia stratiotes: Implications for phytoremediation - Ecotoxicology 13: 637-646.

OECD 2011 - Test No. 201: Freshwater Alga and Cyanobacteria, Growth Inhibition Test - OECD Guidelines for the Testing of Chemicals, Section 2, OECD Publishing, 2011.

Oikari A. 2006 - Caging techniques for field exposures of fish to chemical contaminants - Aquat. Toxicol. 78: 370-381.

Olguín E.J., Hernández E., Ramos I. 2002 - The effect of both different light conditions and the $\mathrm{pH}$ value on the capacity of Salvinia minima Baker for removing cadmium, lead and chromium - Acta Biotechnol. 22: 121-131.

Olson B.H., Clark D.L., Milner B.B., Stewart M.H., Wolfe R.L. 1991 - Total coliform detection in drinking water: comparison of membrane filtration with Colilert and Coliquik - Appl. Environ. Microbiol. 57: 1535-1539.

Orzechowski B. 2005 - Preliminary laboratory investigations of duckweed culture in detergent-contaminated waterSłupskie Prace Biologiczne 2: 49-61 (in Polish).

Pasternak G., Kołwzan B., Dziubek A.M. 2010 - Utilization of microtox toxicity assay in water and wastewater quality assessment - In: Zarządzanie zasobami wodnymi w dorzeczu Odry - 2010 (Ed.) B. Mońka, Wydawnictwo PZITS: 231-238.

Płaza G., Nałęcz-Jawecki G., Ulfig K., Brigmon R.L. 2005 - Assessment of genotoxic activity of petroleum hydrocarbon-bioremediated soil - Ecotox. Environ. Safe. 62: 415-420.

Pogorzelec M., Piekarska K. 2013 - The use of bioluminescent bacteria to detect toxic and mutagenic substances in the environment - Eko-Dok, Wrocław: 524-528 (in Polish).

Prasad M.N.V., Malec P., Waloszek A., Bojko M., Strzałka K. 2001 - Physiological responses of Lemna trisulca L. (duckweed) to cadmium and copper bioaccumulation Plant Sci. 161: 881-889.

Quillardet P., Huisman O., D’Ari R.D., Hofnung M. 1982 SOS chromotest, a direct assay of induction of an SOS function in Escherichia coli K-12 to measure genotoxicity - Genetics 79: 5971-5975.

Robinson B., Kim N., Marchetti M., Moni Ch., Schroeter L., Van den Dijssel C., Milne G., Clothier B. 2006 - Arsenic hyperaccumulation by aquatic macrophytes in the Taupo Volcanic Zone, New Zealand - Environ. Exp. Bot. 58: 206-215.
Rompré A., Servais P., Baudart J., de-Roubin M-R., Laurent P. 2002 - Detection and enumeration of coliforms in drinking water: current methods and emerging approaches $-\mathrm{J}$. Microbiol. Meth. 49: 31-54.

Sadowska U. 2012 - The importance of bioindication in water ecotoxicology - SEeB. 2: 33-52.

Scardi M., Tancioni L., Cataudella S. 2006 - Monitoring Methods Based on Fish - In: Biological Monitoring of Rivers: Applications and Perspectives (Eds) M. Scardi, L. Tancioni, S. Cataudella, Wiley, Sussex, England: 486.

Schneider S., Melzer A. 2003 - The trophic index of macrophytes (TIM) - a new tool for indicating the trophic state of running waters - Int. Rev. Hydrobiol. 88: 49-67.

Steliga T., Kapusta P., Jakubowicz P. 2009 - Assessment of effectiveness of bioremediation processes based on toxicological tests - Wiertnictwo Nafta Gaz. 26: 555-566 (in Polish).

Sun T.S, Stahr H.M. 1993 - Evaluation and application of a bioluminescent bacterial genotoxicity test $-\mathrm{J}$. AOAC Int. 76: 893-898.

Szoszkiewicz K., Zbierska J., Staniszewski R., Jusik S. 2009 The variability of macrophyte metrics used in river monitoring - Oceanol. Hydrobiol. Stud. 38: 117-126.

Traczewska T.M. 2011 - Biological methods for assessing environmental contamination - Traczewska T.M. Wrocław, Poland: 210 (in Polish).

Trepeta R.W., Edberg S.C. 1984 - Methyllumbelliferyl-beta-D-glucuronide-based medium for rapid isolation and identification of Escherichia coli - J. Clin. Microbiol. 19: 172-174.

Trottier S., Blaise C., Kusui T., Johnson E.M. 1997 - Acute toxicity assessment of aqueous samples using a microplate-based Hydra attenuata assay - Environ. Toxicol. Water Qual. 12: 265-271.

Verschaeve L., Van Gompel J., Thilemans L., Regniers L., Vanparys P., van der Lelie D. 1999 - VITOTOX bacterial genotoxicity and toxicity test for the rapid screening of chemicals - Environ. Mol. Mutagen. 33: 240-248.

Wadhia K., Dando T., Thompson K.C. 2007 - Intra-laboratory evaluation of Microbial Assay for Risk Assessment (MARA) for potential application in the implementation of the WFD - J. Environ. Monit. 9: 953-958.

Węgrzyn G., Czyż A. 2003 - Detection of mutagenic pollution of the natural environment using microbiological assays - J. Appl. Microbiol. 95: 1175-1181.

Wolska L., Namiesnik J., Michalska M., Bartoszewicz, M. 2008 - Preliminary study on toxicity of aquatic ecosystems in Bug river basin - Pol. J. Environ. Stud. 17: 811-816.

Woodiwiss F.S. 1964 - The biological system to stream classification used by Trent River Board - Chem. Ind. 11: 443-447.

Zayed A., Terr N. 2003 - Chromium in the environment: factors affecting biological remediation - Plant Soil 249: 139-156. 